Australian Journal of
Crop Science

\title{
Performance of arabica coffee accessions from the active germplasm bank of Minas Gerais, Brazil as a function of dry and wet processing: a sensory approach
}

\author{
Larissa de Oliveira Fassio ${ }^{1}$, Marcelo Ribeiro Malta ${ }^{1 *}$, Gilberto Rodrigues Liska ${ }^{2}$, Gladyston Rodrigues \\ Carvalho $^{1}$, Cesar Elias Botelho ${ }^{1}$, Antônio Alves Pereira ${ }^{1}$, Rosemary Gualberto Fonseca Alvarenga Pereira ${ }^{3}$ \\ ${ }^{1}$ Empresa de Pesquisa Agropecuária de Minas Gerais/EPAMIG - Avenida José Cândido da Silveira, 1647 - \\ Bairro União - 31170-495 - Belo Horizonte, MG, Brasil \\ ${ }^{2}$ Department of Agroindustrial Technology and Rural Socioeconomics, Federal University of São Carlos, \\ Araras, SP, 13600-970, Brazil \\ ${ }^{3}$ Universidade Federal de Lavras/UFLA - Departamento de Ciência dos Alimentos/DCA - Caixa Postal 3037 \\ - 37200-000 - Lavras, MG, Brasil
}

\section{*Corresponding author: marcelomalta@epamig.br}

\section{Abstract}

The post-harvest processing of coffee is one of the most important factors in obtaining a superior quality product with differentiated attributes in the cup. The objective of this study was to evaluate the influence of wet and dry postharvest processing on beverage quality and on the sensory profile of 49 Coffea arabica accessions from the Active Germplasm Bank of Minas Gerais. For this purpose, the sensory analysis was applied based on the protocols of the Specialty Coffee Association, and the data were analyzed by Principal Component Analysis. Some coffee accessions were separated by the final score according to the type of processing used. However, the influence of the processing method was most evident in the individual scores for sensory attributes. Regardless of the processing method, some accessions presented stability for the notes of taste, acidity, fragrance, body, aftertaste, balance, global impression as well as for the final score. The Coffea arabica accessions of the Active Germplasm Bank of Minas Gerais presented variability in the sensory profile of the beverage according to the type of postharvest processing used.

Keywords: Coffea arabica L.; cup quality; genotypes; multivariate analysis; post-harvest.

Abbreviations: AGB_Active Germplasm Bank of Minas Gerais; HCA_Hierarchical Cluster Analysis; NAT_Dry processing; PCA_Principal Components Analysis; SCA_Specialty Coffee Association; FW_Wet processing.

Introduction

The beverage quality of coffee has been highly valued and studied in recent years, corroborating the increase in consumption and credibility to specialty coffees, which are coffees with a set of balanced attributes and no defects. The sensory characteristics that make up a superior quality coffee are primarily associated with the origin of the coffee and with the genotype grown (Ribeiro et al., 2016).

The genus Coffea is diversified and presents about 103 species. However, only two species are commercially cultivated: Coffea arabica L. and Coffea canephora Pierre. The Arabica species represents about $70 \%$ of the coffee produced around the world and is the most appreciated by consumers due to the quality of the beverage characterized by the intense aroma, low bitterness and lower caffeine content (Garret et al., 2013). In genetic improvement programs involving $C$. arabica, the main target is to increase productivity, resistance to diseases and the development of plants of a low size and adapted to various environmental conditions. However, currently, the quality of the beverage is also considered an important factor in works with genetic improvement (Gimase et al., 2014; Leroy et al., 2006; LopezGarcia et al., 2016; Sobreira et al., 2016).

The collection of Coffea accessions of the Active Germplasm Bank of Minas Gerais (AGB) is composed of approximately 1.500 accessions, among them several mutants that represent spontaneous and subspontaneous wild forms of $C$. arabica. Some of these mutations of genetic nature were useful for the development of new cultivars (Lara et al., 2014), some with high beverage quality potential (Fassio et al., 2016; Carvalho et al., 2016).

After the genetic component and the growing environment, one of the factors that most influences the final quality of coffee is post-harvest processing (Barbosa et al. 2019). Basically, there are two methods of post-harvest processing of coffee: dry and wet. In the dry method, the fruits are dried in their integral form, without the removal of exocarp, resulting in natural coffees. In the wet processing method, the exocarp of the fruits is mechanically removed and the parchment coffee is produced (Malta et al., 2013; Taveira et al., 2015). 
Several studies have been developed to investigate the influence of post-harvest processes on coffee beverage quality (Abreu et al., 2015; Barbosa et al., 2019; Clement et al., 2015; Taveira et al., 2015). In this sense, Taveira et al. (2015) and Abreu et al. (2015) found no significant differences for the final score of specialty coffees when processed both dry and wet. However, these same authors and also Clemente et al. (2015) and Arruda et al. (2011) found significant differences in the chemical composition of coffee beans and also in the physiological analyses that evaluate the integrity of the cell membrane according to the type of processing adopted in the post-harvest, which directly impacts the grading of the sensory attributes of the beverage. In this sense, some studies show that the chemical composition and physiological structure of coffee beans depend on the form of processing method (Borém et al., 2013; Taveira et al., 2014), contributing to distinct sensory characteristics in the cup quality (Malta et al., 2013; Oliveira et al., 2013). In addition, metabolic reactions involved in the germination of coffee seeds are strongly determined by the post-harvest processing method, influencing the quality of the beverage (Selmar, Kleinwächter and Bytof, 2015).

In this context, the objective of this study was to evaluate the influence of wet and dry processing on beverage quality and on the sensory profile of $C$. arabica accessions of the Active Germplasm Bank of Minas Gerais.

\section{Results and discussion}

\section{Principal Components Analysis (PCA)}

The PCA is a multivariate analysis that provides a visual representation of the data and does not require prior knowledge of the data set. The PCA was applied to investigate the effect of the type of processing (natural or pulped) on the sensory quality of 49 accessions of $C$. arabica $L$. from the AGB. The attributes sweetness, absence of defects and uniformity were not statistically evaluated because these variables did not present differences in the scores for all the accessions evaluated.

The biplot of the sensory variables can be seen in Figure 1 (a) and the projection of the Arabica coffee accessions for the two types of processing can be seen in Figure 1 (b). According to the PCA, the first two main components explained $81.30 \%$ of total response variability $(72.75 \%$ for PC1 and $8.55 \%$ for PC2), when comparing the accessions of C. arabica as a function of processing (Figure 1a). According to PC1, all the variables evaluated had a strong influence on the separation of the groups of coffee accessions according to the type of processing (Table 1). Five distinct groups of coffee accessions were formed in two types of processing according to the sum of the sensory attribute scores (Figure $1 \mathrm{~b}$ and Figure 2). The group $\mathrm{V}$, composed only of accession 33 (Obatã Tardio/pulped coffee), presenting the highest sensorial score among the accessions submitted to wet processing (i.e., 90.2 points). The group IV, on the other hand, composed only of the accession 36 (Híbrido Timor UFV 376-52/natural coffee), was the accession with the highest score in dry processing with 86.1 points. The group I was formed with accessions with final scores between 84.3 and 85.8 points. The group II formed by accessions with final scores between 82.9 and 84.2 points, which was the group where most accessions were allocated. The group III, with final scores between 80.8 and 82.8 points, was the group of accessions with the lowest scores. Therefore, all AGB coffee accessions evaluated, regardless of the type of processing used, natural or pulped, were considered specialty coffees, since they had a score above 80 , which is the threshold/minimum score to be considered specialty coffee (Lingle, 2011).

There is variability in the coffee quality of some Arabica coffee accessions depending on the type of processing. For example, accession 33 (Obatã tardio) reached a score of 90.2 points in wet processing and 84.6 points in dry processing. This same behavior was also observed in accession 43 (BE 5Wush-Wush UFV 406-06) since this accession had a score of 85.7 in dry processing and 82.5 in wet processing. In this case, it is clearly noted that the type of processing adopted in the post-harvest has a considerable influence on the sensory expression of these accessions. Leroy et al. (2006) proposed that processing methods in post-harvest stage can affect the beverage quality of the coffee. The rapid removal of the peel and mucilage of the coffee, as it happens in wet processing, makes it easier to obtain a good coffee beverage quality, regardless of the production area and, when properly prepared, are always classified as a beverage of high commercial value (Oliveira et al, 2013). Corroborating this study, Malta et al. (2013) also observed significant differences in the final scores, between the natural and pulped processes. However, according to the same authors, it is possible to obtain specialty coffees using natural processing, as long as well-performed harvesting and postharvest are executed.

Several studies have been developed to investigate the influence of post-harvest processes on coffee beverage quality. In this sense, Taveira et al. (2015) and Abreu et al. (2015) found no significant differences for the final score of specialty coffees, when processed both dry and wet. However, these same authors and also Clemente et al. (2015) and Arruda et al. (2011) found significant differences in the chemical composition of coffee beans and also in the physiological analyses that evaluate the integrity of the cell membrane according to the type of processing adopted in the post-harvest, which directly impacts the grading of the sensory attributes of the beverage.

It is currently known that coffees subjected to natural and pulped processing originate beverages with distinct sensory profiles, even with very similar final scores (Taveira et al., 2015). Therefore, for assessment of specialty coffees quality, it is important to consider all the sensory attributes observed in the cup, since there is already a significant share in the specialty market, in which different characteristics are valued.

According to PC1 (Figure 3), accession 33 (Obatã tardio) submitted to wet processing was the one that presented the highest scores for sensory attributes and consequently in the final score. Also, the accessions 36 (Híbrido Timor UFV 37652 ), 38 (Híbrido Timor UFV 376-01), 46 (Sarchimor UFV 35001), 43 (BE 5Wush-Wush UFV 406-06) and 39 (Híbrido Timor UFV 427-09) were also highlighted. They were all submitted to natural processing. The BE5 Wush-Wush accession originates from Ethiopia, with the $\mathrm{SH} 1$ resistance factor (Rodrigues, Braghini and Guerreiro Filho, 2017) and has red fruits with early and uniform ripeness. The Híbrido Timor genotype comes from the interspecific crossing of $C$. arabica and $C$. canephora and the descendants of this genotype are widely used in genetic improvement to promote resistance to various diseases of the coffee tree (Romero et al., 2014). In addition to being resistant to coffee tree diseases, other 
Table 1. Correlations between the evaluated parameters (sensorial attributes) with the first two main components and the respective coefficients of each parameter with the main component.

\begin{tabular}{lllll}
\hline \multirow{2}{*}{ Parameters } & \multicolumn{2}{c}{ PC1 (72.75\%) } & \multicolumn{2}{c}{ PC2 (8.55\%) } \\
\cline { 2 - 5 } & Coeffcients & Correlations* & -0.0550 & -0.0425 \\
\hline Fragrance & -0.3784 & -0.8540 & -0.3241 & -0.2507 \\
Flavor & -0.3922 & -0.8851 & 0.3215 & 0.2486 \\
Acidity & -0.3780 & -0.8531 & -0.4402 & -0.3405 \\
Body & -0.3462 & -0.7814 & -0.4340 & -0.3357 \\
Aftertaste & -0.3827 & -0.8637 & 0.4676 & 0.3617 \\
Balance & -0.3749 & -0.8459 & 0.4334 & 0.3352 \\
Overall & -0.3914 & -0.8832 & & \\
\hline
\end{tabular}

* Variables in bold and italics indicate groups of variables to be formed.

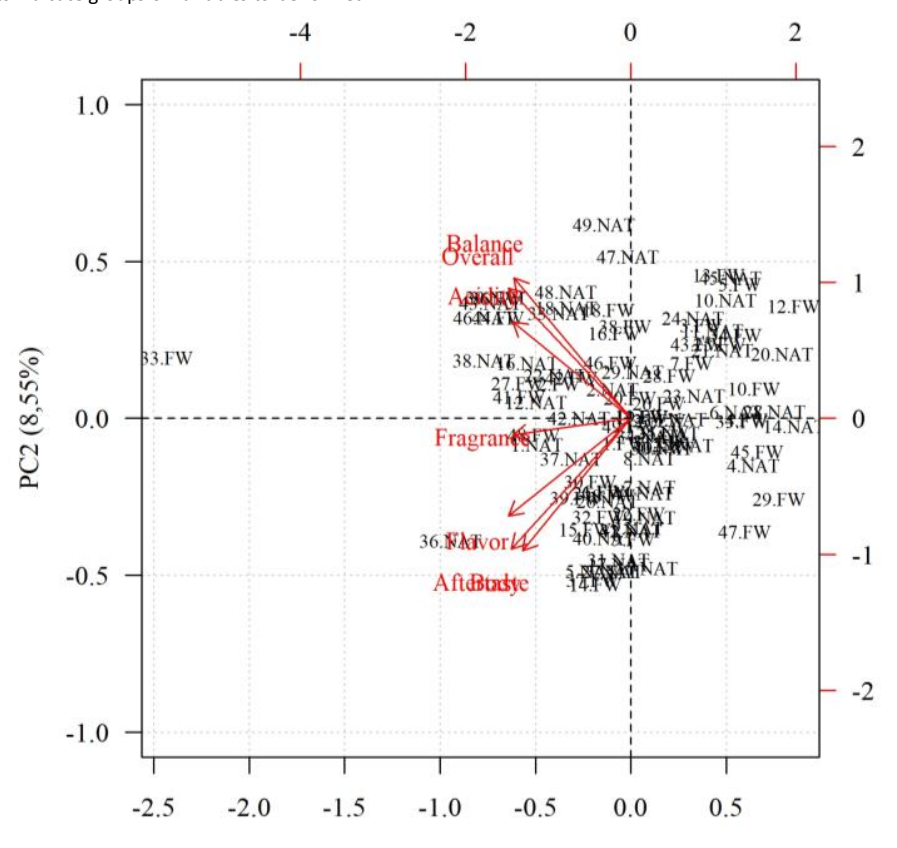

$\operatorname{PC} 1(72.75 \%)$

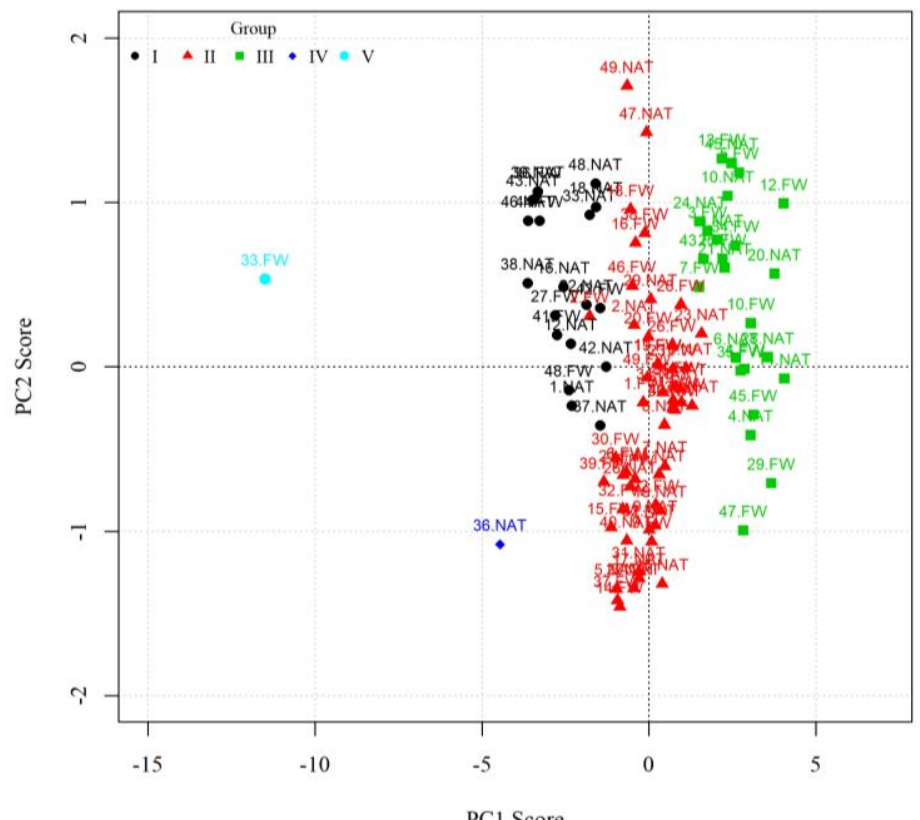

Fig 1. Biplot of variables (A) and PCA scores (B) for C. arabica accessions from the AGB, as a function of wet processing (FW) and dry processing (NAT), in relation to the sensory attributes of coffee. (Black circle) Group I: 84.3 - 85.8 points, (Red triangle) Group II: 82.9 - 84.2 points, (Green square) Group III: 80.8 - 82.8 points, (Purple rhombus) Group IV: 86.1 points, (Light blue circle ) Group V: 90.2 points (numbers refer to genotype code in Table 2). Group I: Black circle; Group II: Red triangle; Group III: Green square; Group IV: Purple rhombus; Gropu V: Light blue circle. 
Table 2. Code and identification of 49 accessions of $C$. arabica from the AGB.

\begin{tabular}{|c|c|c|c|}
\hline $\begin{array}{l}\text { Genotype } \\
\text { Code }\end{array}$ & $\begin{array}{l}\text { Genotype } \\
\text { Identification }\end{array}$ & $\begin{array}{l}\text { Genotype } \\
\text { Code }\end{array}$ & $\begin{array}{l}\text { Genotype } \\
\text { Identification }\end{array}$ \\
\hline 1 & Bourbon Amarelo & 26 & Pacamara \\
\hline 2 & Bourbon Amarelo & 27 & Pacamara \\
\hline 3 & Bourbon Vermelho & 28 & Laurina \\
\hline 4 & Bourbon Vermelho & 29 & Catuaí Erecta \\
\hline 5 & Bourbon Amarelo T7 & 30 & Erecta \\
\hline 6 & Bourbon Amarelo T8 & 31 & Obatã Amarelo \\
\hline 7 & Bourbon Amarelo T13 & 32 & Trifolia \\
\hline 8 & Bourbon Amarelo T15 & 33 & Obatã Tardio \\
\hline 9 & Bourbon Vermelho & 34 & Catucaí Amarelo SL 6 \\
\hline 10 & Sumatrão Ponta Roxa & 35 & Catuaí Vermelho PI 06 \\
\hline 11 & Sumatra & 36 & Híbrido Timor UFV 376-52 \\
\hline 12 & Sumatrão Ponta Roxa & 37 & Híbrido Timor UFV 376-37 \\
\hline 13 & Planta Roxa & 38 & Híbrido Timor UFV 376-01 \\
\hline 14 & Icatu Precoce IAC 3282 & 39 & Híbrido Timor UFV 427-09 \\
\hline 15 & Maragogipe & 40 & Mundo Novo x S 795 UFV 335-15 \\
\hline 16 & Caturra X H.T. IAC 2012 & 41 & Bourbon N39 x H.T. UFV 455-01 \\
\hline 17 & Caturra Alaranjado & 42 & Bourbon N197 x H.T.UFV 403-19 \\
\hline 18 & Caturra Amarelo & 43 & BE 5 Wush-Wush UFV 406-06 \\
\hline 19 & Caturra Amarelo & 44 & Mundo Novo x CIFC H 288/4 UFV 323-59 \\
\hline 20 & Caturra Amarelo Colombiano & 45 & Geisha x S 288/23 UFV 328-69 \\
\hline 21 & Caturra Vermelho UFV 534 C83 & 46 & Sarchimor UFV 350-01 \\
\hline 22 & Caturra Vermelho UFV 534 C80 & 47 & Bourbon Vermelho \\
\hline 23 & Caturra Amarelo & 48 & Sumatra fruto amarelo \\
\hline 24 & Caturra Amarelo & 49 & Mundo Novo II CP 388-17-16 \\
\hline 25 & Caturra Amarelo Nanição & & \\
\hline
\end{tabular}

studies confirm that the Híbrido Timor germplasm can be used as a source of genes to improve other characters of interest, such as the coffee beverage quality (Sobreira et al., 2015).

The type of post-harvest processing can interfere with the expression of sensory attributes of coffee accessions, as can be observed in the explanation of PC2 (Table 1). The sensory attributes such as flavor, acidity, body, aftertaste, balance and overall impression were determinants for the formation of PC2, being influenced by groups of variables. Thus, it was observed that 7 of the 10 accessions of coffee with higher scores for the attributes of flavor, body, and aftertaste were processed by the natural method (Figure 4). The results obtained corroborate with what is proposed in the literature, that the type of post-harvest processing influences the sensory attributes of the beverage (Oliveira et al., 2013; Taveira et al., 2015). In a study on coffee processing, Malta et al. (2013) also observed significant differences in sensory attributes depending on the processing method adopted, with pulped coffees showing higher values for acidity and natural coffees higher values for the flavor attribute. Usually, natural coffees produce fuller and sweeter beverages, while pulped coffees have a more desirable acidity beverage (Taveira et al., 2015).

Also according to PC2, the accessions 2 (Bourbon Amarelo), 10 (Sumatrão Ponta Roxa), 16 (Caturra X H.T. IAC 2012), 18 (Caturra Amarelo), 20 (Caturra Amarelo Colombiano), 33 (Obatã Tardio), 38 (Híbrido Timor UFV 376-01), 43 (BE5 Wush-Wush UFV 406-06) and 46 (Sarchimor UFV 350-01), regardless of the type of processing, presented higher scores for the acidity, balance and overall impression attributes. Similarly, the accessions 1 (Bourbon Amarelo), 8 (Bourbon Amarelo T15), 9 (Bourbon Vermelho), 15 (Maragogipe), 17 (Caturra Alaranjado), 30 (Erecta), 31 (Obatã Amarelo), 32 (Trifolia), 37 (Híbrido Timor UFV 376-37) and 40 (Mundo

Novo x S 795 UFV 335-15), presented the highest scores in relation to taste, body and aftertaste attributes.
It is noted that the exotic accessions, such as the BE5 WushWush, the Híbrido Timor germplasm and the Pacamara presented the capacity to produce coffee with beverage quality very similar to Bourbon and its derivatives, Caturra, and Mundo Novo. The Bourbon cultivar is known worldwide for its potential to produce excellent beverage coffees, being widely used in the specialty coffee market, and also as a progeny in improvement programs aimed at improving beverage quality (Ferreira et al, 2012; Figueiredo et al., 2013; Leroy et al., 2006). Sobreira et al. (2015) evaluated the sensory attributes of accessions of $C$. arabica $\mathrm{L}$. and also found the superiority of the accessions of Híbrido Timor group in relation to the Bourbon, Caturra, Catimor, and Traditional Cultivars groups.

\section{Cup quality stability of accessions as a function by postharvest processing}

From the results observed here, it is possible to infer that the accessions 2 (Bourbon Amarelo), 33 (Obatã Tardio), 36 (Híbrido Timor UFV 376-52), 37 (Híbrido Timor UFV 376-37), 39 (Híbrido Timor UFV 427-09), 42 (Bourbon N197 x H.T.UFV 403-19) and 48 (Sumatra Fruto Amarelo), introduced in the $A G B$, present greater stability for the sensory attributes of the coffee beverage, regardless of the type of processing adopted, because they are allocated in the groups with better beverage quality. Coffee genetic improvement programs around the world are looking for genetic resources, especially with regard to the sensory attributes of the beverage to produce differentiated coffees for the specialty coffee market. Several studies have demonstrated genetic variability in C. arabica germplasm (Garret et al., 2013; Aerts et al., 2013). However, due to the intrinsic difficulties of a standardized assessment, the information is 


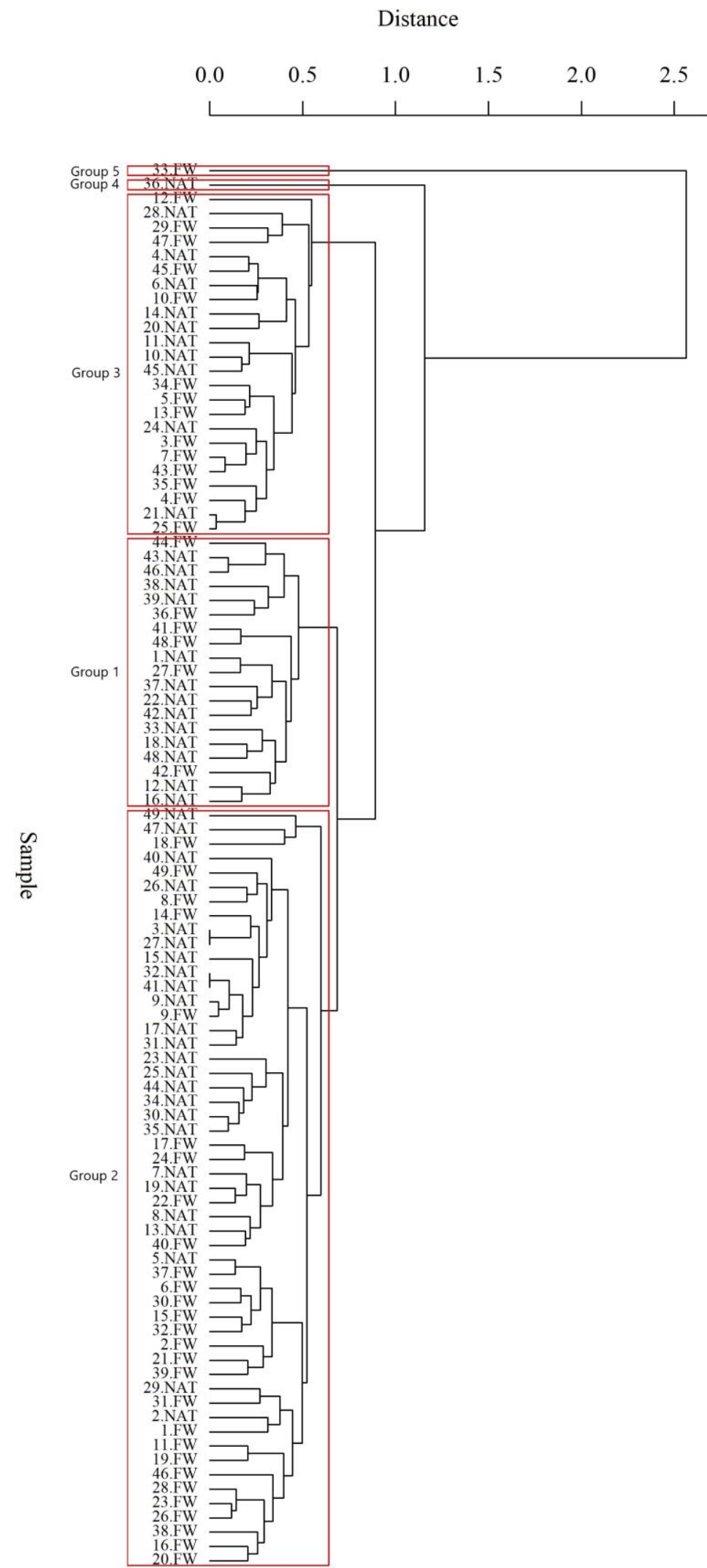

Fig 2. Hierarchical Cluster Analysis dendrogram for 49 accessions of Coffea arabica L. from the AGB as a function of wet processing (FW) and dry processing (NAT), in relation to the sensory attributes of coffee. Group I: $84.3-85.8$ points, Group II: 82.9 - 84.2 points, Group III: 80.8 - 82.8 points, Group IV: 86.1 points, Group V: 90.2 points (numbers refer to genotype code in Table 2). 

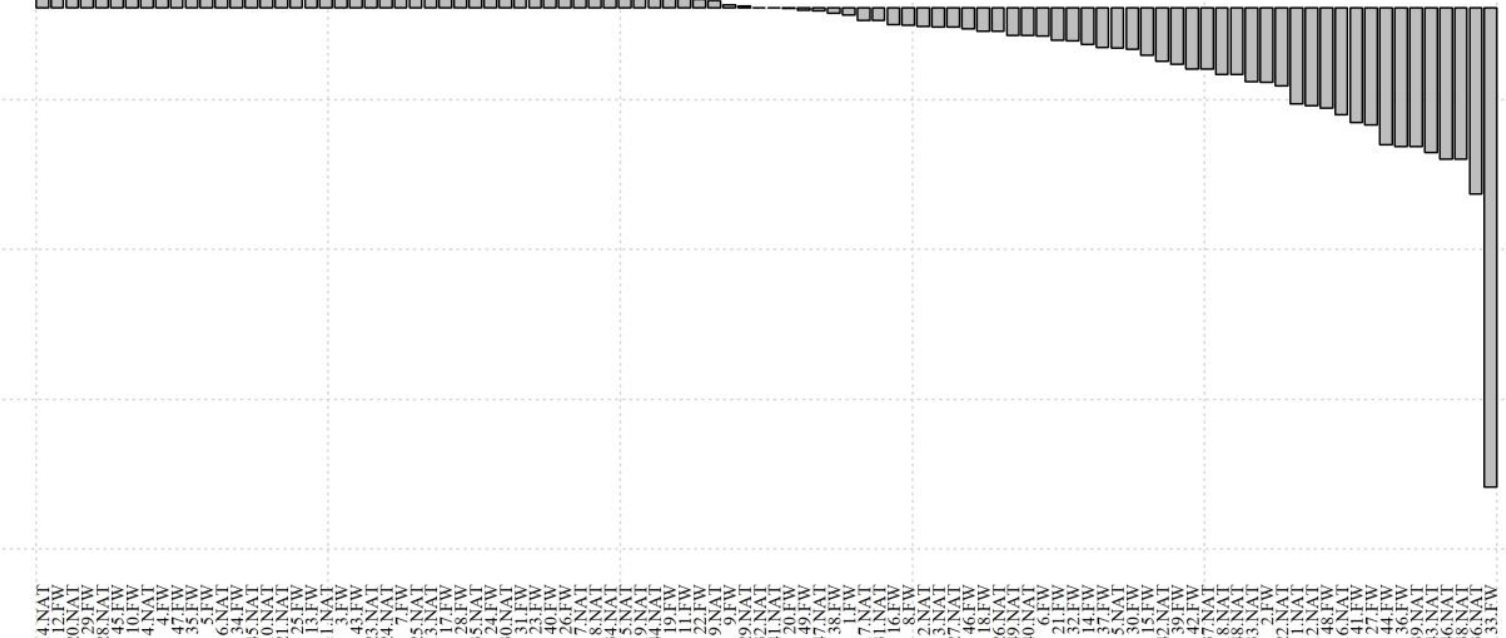

Fig 3. PC1 scores for data of 49 accessions of C. arabica from the AGB as a function of wet processing (FW) and dry processing (NAT), according to the scores of sensorial attributes (numbers refer to genotype code in Table 2).

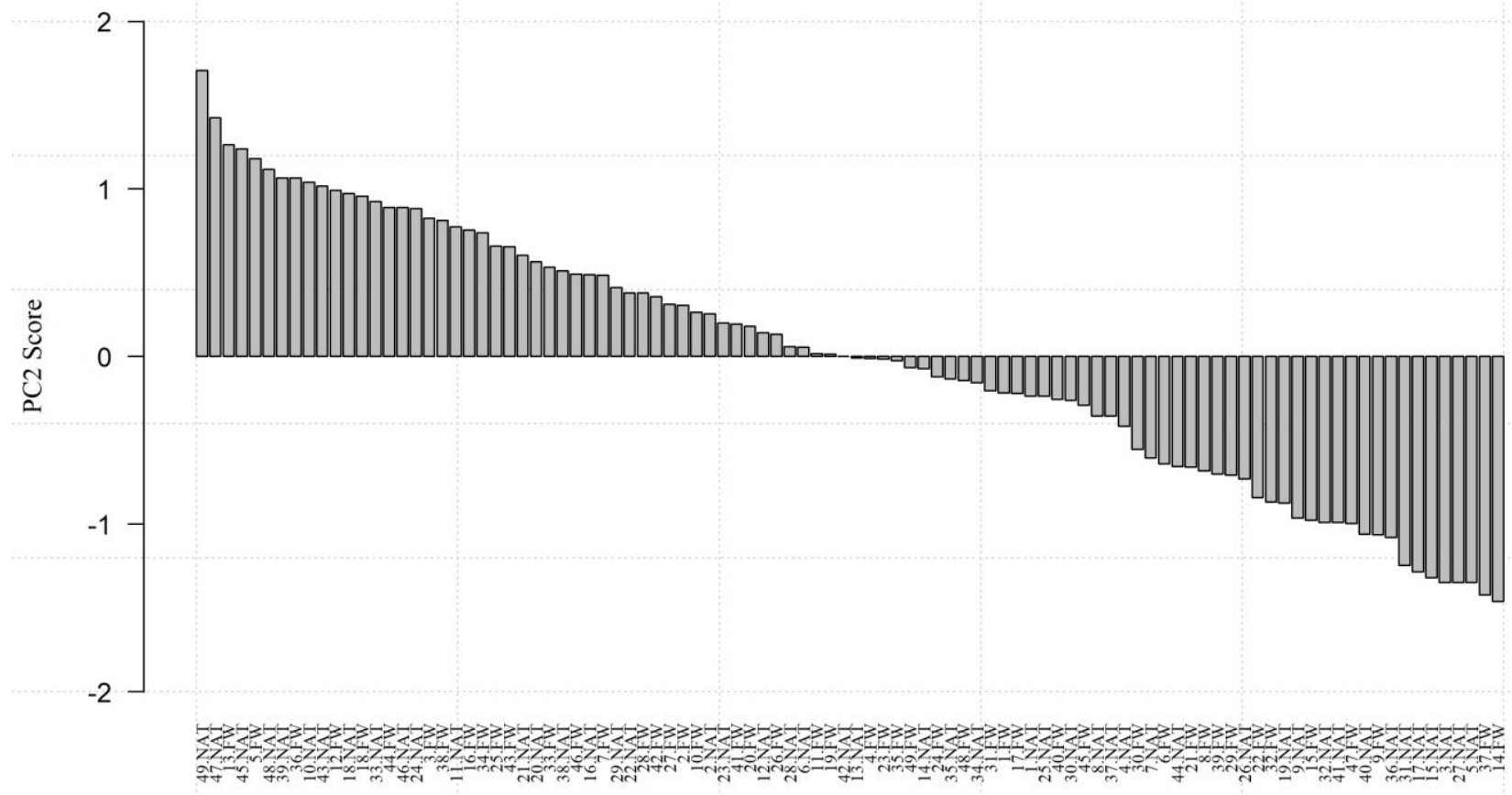

Fig 4. PC2 scores for data of 49 accessions of $C$. arabica from the $A G B$ as a function of wet processing (FW) and dry processing (NAT), according to the scores of sensorial attributes (numbers refer to genotype code in Table 2). 


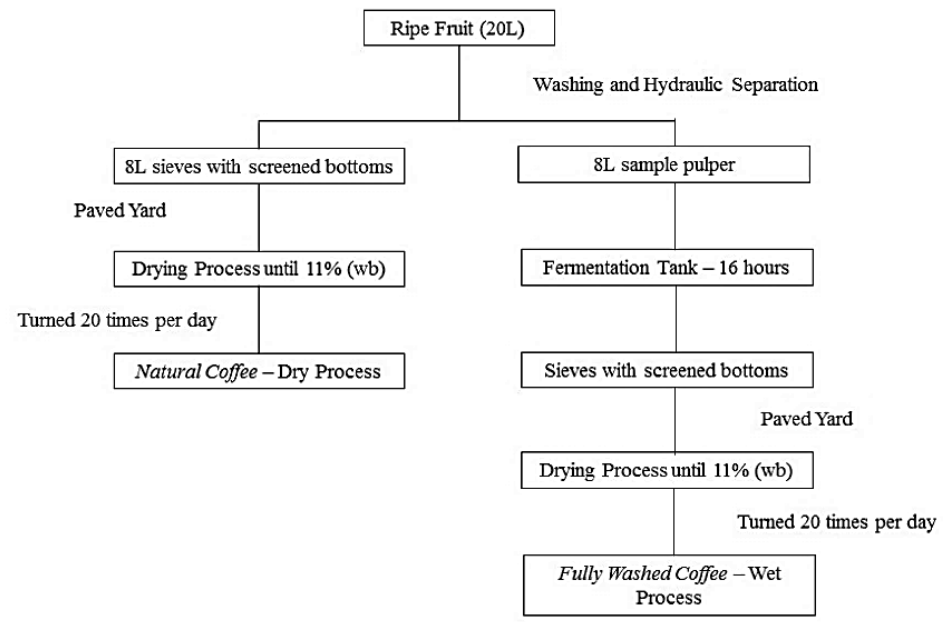

Fig 5. Flowchart of the dry processing (natural coffee) and wet processing (FW) methods used to process the Coffea arabica accessions from the AGB.

not clear about how far apart the cultivars or accessions are from each other in relation to the sensory profile, which reduces the likelihood of quality gains after a selection and recombination process. Studies aimed at the potential for quality of accessions of coffee germplasm collections (Sobreira et al., 2016; Sobreira et al., 2015; Gimase et al, 2014) generally use only one type of processing to define the sensory profile of the accessions. However, understanding the importance of post-harvest processes in defining the sensory attributes of the beverage, like this work, is very important. In the current work, the beverage quality of processed coffee both wet and dry are presented. This may represent, the potential genetic gains for future selection.

Currently, it is common in the specialty coffee market to look for beans with differentiated sensory profiles that add value and determine the uniqueness of the beverage. These differences can be influenced mainly by the coffee processing and drying stages, in which the beans are subject to chemical, biochemical and physiological changes. Based on the results obtained in this study, it can be stated that the Active Germplasm Bank of Minas Gerais has accessions with variability in the sensory profile depending on the type of post-harvest processing adopted.

\section{Materials and methods}

\section{Description of the study site}

The Active Germplasm Bank of Minas Gerais (AGB) is installed in the Experimental Farm of Patrocínio of the Agricultural Research Company of Minas Gerais - EPAMIG,

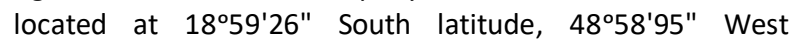
longitude and 975 meters of altitude, in the Alto Paranaíba region. The soil type was Oxisol with flat topography, with a slight inclination. The climate of Patrocínio is a Temperate Subtropical Mesothermal Climate, with rains of summer, hot summer and dry winter (Wca), according to Koppen classification.

\section{Accessions assessed}

Forty-nine accessions of $C$. arabica from AGB were assessed, processed dry (natural coffee) and wet (pulped coffee), in the 2016 harvest. The description of the accessions is presented in Table 2.

\section{Sample collection, processing, and preparation}

The coffee fruits from AGB were harvested selectively when most were at their ideal ripening point, i.e., cherry fruits. Twenty liters of ripe fruit from each coffee access were processed dry (natural coffee) and wet (pulped coffee), according to the flowchart in Figure 5. After reaching the ideal water content, the coconut and parchment samples were packed in $\mathrm{Kraft}^{\circledR}$ paper packaging and coated with a polyethylene bag. Then, they were stored in a cold room with a controlled temperature at $17^{\circ} \mathrm{C}$ for a period of 30 days to then be processed and submitted to sensory analysis.

\section{Sensory analysis}

The roasting and the sensory analysis of the samples were performed based on the protocols described by the Specialty Coffee Association - SCA (Lingle, 2011). 100g of coffee beans (sieve 16 and above without defects) of each sample were roasted until they reached the standard color \#65 for whole beans of the Agtron/SCA Color Classification System, respecting the time range of 8 to 12 minutes. For sensory analysis, a panel of three trained judges (Q-grader) evaluated five cups of each sample in relation to ten attributes, fragrance/aroma, uniformity, absence of defects, sweetness, flavor, acidity, body, balance, finish and overall impression, which were graded on a 10-point scale with intervals of 0.25 points. The final sensorial score was generated from the sum of the evaluated attributes, being considered special those coffees with a score equal to or higher than 80 points.

\section{Statistical analysis}

Forty-nine Arabica coffee accessions were evaluated using two processing methods (natural and pulped). The design used was of casualized blocks (CBD), with two repetitions and parcels with ten plants each. The results of the sensory attributes of the coffees were submitted to multivariate analysis for a better understanding of the effect of the 
variables studied. To this end, the Principal Components Analysis (PCA) was used for the discrimination of coffee accessions, from the interaction with post-harvest processing, resulting in the grouping of points according to sensory attributes. Hierarchical Cluster Analysis (HCA) was also used in order to visualize the structure and similarity between the samples as a complement to the PCA. For this analysis, we used the statistical software R ( $R$ Development Core Team, 2017).

\section{Conclusions}

The Coffea arabica accessions from the Active Germplasm Bank of Minas Gerais presented variability in the quality and in the sensory profile of the beverage due to post-harvest processing. Some coffee accessions, regardless of the type of processing adopted, presented higher scores for the sensory attributes of the beverage, demonstrating greater sensory stability of these accessions while other accessions present variability in sensory attributes according to the type of processing applied.

\section{Acknowledgments}

The authors acknowledge the Agricultural Research Company of Minas Gerais (EPAMIG), the Federal University of Lavras (UFLA), the Coffee Innovation Agency (INOVACAFE), the Consórcio de Desenvolvimento Pesquisa Café, FAPEMIG, CNPq, and CAPES.

\section{References}

Abreu GF, Pereira CC, Malta MR, Clemente ACS, Coelho LFS, Rosa SDVF (2015) Alterações na coloração de grãos de café em função das operações pós-colheita. Coffee Science. 10: 429-436.

Aerts R, Berecha G, Gijbels P, Hundera K, Glabeke S, Vandepitte K, Muys B, Roldán-Ruiz I, Honnay O (2013) Genetic variation and risks of introgression in the wild Coffea arabica gene pool in south-western Ethiopian montane rainforests. Evol Appl. 6:243-252.

Arruda NP, Hovell AMC, Rezende CM, Freitas SP, Couri S, Bizzo HR (2011) Discriminação entre estádios de maturação e tipos de processamento de pós-colheita de cafés arábica por microextração em fase sólida e análise de componentes principais. Quim Nova. 34:819-824.

Barbosa IP, Oliveira ACB, Rosado RDS, Sakiyama NS, Cruz CD, Pereira AA (2019). Sensory quality of Coffea arabica L. genotypes influenced by postharvest processing. Crop Breed Appl Biotechnol. 4:428-435.

Borém FM, Oliveira PD, Isquierdo EP, Giomo GS, Saath R, Cardoso RA (2013) Scanning electron microscopy of coffee beans subject to diferente forms processing and drying. Coffee Science. 8:277-237.

Carvalho AM, Rezende JC, Rezende TT, Ferreira AD, Rezende RM, Mendes ANG, Carvalho, GR (2016) Relationship between the sensory attributes and the quality of coffee in different environments. Afr J Agric Res. 11: 3607-3614.

Clemente ACS, Cirillo MA, Malta MR, Caixeta F, Pereira CC, Rosa SDVF (2015) Post-harvest operations and physicochemical and sensory quality of coffees. Coffee Science. 10:233-241.

Fassio LO, Malta MR, Carvalho GR, Liska GR, Lima PM, Pimenta CJ (2016) Sensory description of cultivars (Coffea arabica L.) resistant to rust and its correlation with caffeine, trigonelline, and chlorogenic acid compounds. Beverages. 2:1-12.

Ferreira AD, Mendes ANG, Carvalho GR, Botelho CE, Malta MR (2012) Análise sensorial de diferentes genótipos de cafeeiro Bourbon. Interciencia. 37:390-394.

Figueiredo LP, Borém FM, Cirillo MA, Ribeiro FC, Giomo GS, Salva TJ (2013) The potential for high-quality Bourbon coffees from different environments. J Agric Sci. 5: 87-98.

Garret R, Schmidt EM, Pereira LFP, Kitzberger CSG, Scholz MBS, Eberlin MN, Rezende CM (2013) Discrimination of arabica coffee cultivars by electrospray ionization Fourier transform ion cyclotron resonance mass spectrometry and chemometrics. Food Sci Technol - LEB. 50:496-502.

Gimase JM, Thagana WM, Kirubi DT, Gichuru EK, Kathurima CW (2014) Beverage quality and biochemical attributes of arabusta coffee (C. arabica L. $\times$ C. canephora Pierre) and their parental accessions. Afr J Food Sci. 8:456-464.

Lara JMRA, Rezende JC, Carvalho GR, Pereira AA, Carvalho JPF, Guerreiro Filho O (2014) Caracterização de formas botânicas diversas do Banco Ativo de Germoplasma de cafeeiros do Estado de Minas Gerais, Brasil. Bragantia. 73:383-389.

Leroy T, Ribeyre F, Bertrand B, Charmetant P, Dufour M, Montagnon C, Marraccini P, Pot D (2006) Genetics of coffee quality. Braz J Plant Physiol. 18:229-242.

Lingle TR (2011) The coffee cupper's handbook: a systematic guide to the sensory evaluation of coffee's flavor. Long Beach, CA: Specialty Coffee Association of America.

Lopez-Garcia FJ, Escamilla-Prado E, Zamarripa-Colmenero A, Cruz-Castillo JG (2016) Produción y calidad en variedades de café (Coffea arabica L) en Veracruz, Mexico. Rev Fitotec Mex. 39:297-304.

Malta MR, Rosa SDVF, Lima PM, Fassio LO, Santos JB (2013) Alterações na qualidade do café submetido a diferentes formas de processamento e secagem. Rev Eng Agric. 21:431-440.

Oliveira PD, Borém FM, Isquierdo EP, Giomo GS, Lima RR, Cardoso RA (2013) Physiological aspects of coffee beans, processed and dried through different methods, associated with sensory quality. Coffee Science. 8:203-211.

$R$ Development core team. R. a language and environment for statistical computing. Vienna: Foundation for Statistical Computing, 2017. [accessed 2017 April 26]. http://www.Rproject.org/.

Ribeiro DE, Borém FM, Cirillo MA, Prado MVB, Ferraz VP, Alves HMR, Taveira JHS (2016) Interaction of genotype, environment and processing in the chemical composition expression and sensorial quality of Arabica coffee. Afric J Agric Res. 11:2412-2422.

Rodrigues LMR, Braghini MT, Guerreiro Filho O (2017) SH1 leaf rust and bacterial halo blight coffee resistances are genetically independent. Bragantia, 76, 209-213.

Romero G, Vásquez LM, Lashermes P, Herrera JC (2014) Identification of a major QTL for adult plant resistance to coffee leaf rust (Hemileia vastatrix) in the natural Timor hybrid (Coffea arabica $x$ Coffea canephora). Plant Breeding. 133:121-129.

Selmar D, Kleinwachter M, Bytof G (2015) Metabolic responses of coffee beans during processing and their impact on coffee flavor. In: R. F. Schwan and G. H. Fleet (Eds.), Cocoa and Coffee Fermentations (p.431-476). Boca Raton: CRC Press. 
Sobreira FM, Oliveira ACB, Pereira AA, Sakyiama NS (2015) Potential of Híbrido de Timor germplasm and its derived progenies for coffee quality improvement. Aust J Crop Sci. 9:289-295.

Sobreira FM, Oliveira ACB, Pereira AA, Garçoni AM, Sakiyama NS (2016) Divergence among arabica coffee accessions for sensory quality. Aust J Crop Sci. 10:14421448.
Taveira JHS, Borém FM, Figueiredo LP, Reis N, Franca AS, Harding SA, Tsai CJ (2014) Potential markers of coffee accessions grown in different Brazilian regions: A metabolomics approach. Food Res Int. 61:75-82.

Taveira JHS, Borém FM, Rosa SDVF, Oliveira PD, Giomo GS, Isquierdo EP, Fortunato VA (2015) Post-harvest effects on beverage quality and physiological performance of coffee beans. Afric J Agric Res. 10:1457-1466. 